\title{
THE EFFECT OF HEAT TREATMENT ON THE DURABILITY OF BAMBOO Gigantochloa scortechinii
}

\author{
Norashikin Kamarudin $^{1}$ and Krisdianto Sugiyanto ${ }^{2}$
}

\begin{abstract}
Bamboo signifies as one of the fastest growing plants and it can be used for various products. In tropical countries such as Indonesia and Malaysia, bamboo is abundantly available at reasonable prices, therefore it is used for numerous purposes. However, as lignocellulosic material, bamboo is susceptible to fungal and insect attacks. Heat treatment is an option to improve bamboo's durability. The objective of this study was to improve the durability of bamboo using hot oil palm treatment. A Malaysian grown bamboo species, Buluh Semantan (Gigantochloa scortechinii), as a study material was soaked in hot oil palm for various temperatures and soaking time, before being inoculated with the basidiomycete Coriolus versicolor in an agar block test. The results demonstrated that the longer the heating time, the more improved the durability of bamboo. Altering the temperature in the palm oil treatment produced varying results. Bamboo blocks that heated in hot oil palm at $100^{\circ} \mathrm{C}$ for 60 minutes shows considerably less weight reduction that indicates less fungal attack. Overall, the higher the temperature, the better the durability of bamboo. Please indicates what the meaning of heat treatment in this experiment, it is not clear.
\end{abstract}

Keywords: Durability, heat treatment, bamboo, Gigantochloa scortechinii, Coriolus versicolor

\section{INTRODUCTION}

Bamboo is known as one of the fastest growing plants and being used for various household utilities such as containers, chopsticks, woven mats, fishing rod, cricket boxes, handicrafts and chairs. Bamboo is abundant in the topics (over 75 genera and 1250 species) ranging from small grasses to large varieties over 40 metres in height and 0.3 metres in diameter (Tewari, 1993). Bamboo is being used for housing construction (poles, purlins, rafters, and trusses), mats (flat board substituition), floating ladder fenders, furniture, handicraft articles and baskets. Inspite of its advantageous, bamboo is susceptible to fungal or insect attack. Moreover, dry bamboo is difficult to treat with preservatives due to its refractory and impervious nature (Liese, 1980).

\footnotetext{
${ }^{1}$ Lecturer, Universiti Teknologi MARA (UiTM), Shah Alam, 40450, Selangor, Malaysia.

${ }^{2}$ Researcher, Forestry Engineering and Forest Product Processing Center, Jl. Gunung Batu 5, Bogor, Indonesia
}

Natural durability of bamboo varies from species to species as well as in service application and location of use. Bio-deterioration of culms are caused by soft rot, white rot and brown rot fungi. Bamboo consists of 50-70\% hemicellulose, $30 \%$ pentosans and 20-25\% lignin (Tamolang et al., 1980; Chen et al., 1985). Data outlining the natural durability of bamboo is limited. Losses due to biological degradation occur even during storage especially when bamboo is not properly protected.

Generally the treatment of bamboo is carried out in either green or dry condition for various end uses. Currently, there is no standard method for preserving bamboo (Liese, 1985). The presence of considerable quantities of starch in green or dry bamboo makes it more attractive to such organisms, especially fungal stain and borer beetles (Beeson, 1941; Gardener, 1945; Mathew et al., 1990; Gnanahran et al., 1993). Traditional preservation methods have been applied, such as leaching in water and mud, starch removal, baking and smoking, however, traditional method cannot 
be controlled and excessive heating in smoking or baking can cause severe collapse (Rehman and Ishaq, 1947). This paper is aiming to investigate palm oil heat treatment for bamboo and its durability against fungal attack (Coriolus versicolor).

\section{MATERIALS AND METHODS}

Sixty blocks of the Malaysian grown bamboo species, Buluh Semantan (Gigantochloa scortechinii) were prepared for testing. Bamboo blocks free from the outer and inner part of its stem were prepared in dimension of $25 \times 25 \times 9 \mathrm{~mm}$. A total of 54 samples were treated with an additional of six samples being used as controls.

\section{A. Heat treatment}

Labelled test bamboo blocks were equilibrated for 24 hours on screen trays to constant weight in a conditioning room $\left(27 \pm 1^{\circ} \mathrm{C}, 70 \%\right.$ relative humidity). Afterwards, all test specimens were weighed to the nearest $0.01 \mathrm{~g}$. The blocks were heated at hot oil palm with various temperature of $100^{\circ} \mathrm{C}, 150^{\circ} \mathrm{C}$ and $200^{\circ} \mathrm{C}$ for various soaking time: 20, 40 and 60 minutes consecutively. Bamboo blocks were soaked into hot palm oil when the oil reached the targeted temperature. After treatment the blocks were shaken on a sieve to remove excess oil and re-weighed $\left(\mathrm{W}_{1}\right)$. The untreated bamboo blocks were included as controls for comparison with the treated samples. Are $100^{\circ} \mathrm{C}$, $150^{\circ} \mathrm{C}$ and $200^{\circ} \mathrm{C}$ temperatures $=$ hot palm oil, please more clear.

\section{B. Biological testing}

Sterile nutrient malt agar (20 g per litre) was prepared as the growth media, then put into the glass bottles (250 $\mathrm{cm}^{3}$ capacity) used for the exposure of the bamboo blocks to the test fungi (Coriolus versicolor). Bottles before being used for such were previously sterilized in an autoclave at $121^{\circ} \mathrm{C}$ for 30 minutes. Bottles were then inoculated with $10 \mathrm{~mm}$ squares of Coriolus versicolor taken from the outer edge of the fungal cultures. All inoculated bottles were incubated in conditioning room $\left(27 \pm 1^{\circ} \mathrm{C}, 70 \%\right.$ relative humidity) with slightly loosened lids until the malt agar surface was covered by mycelium. Three blocks as a replicate were then exposed to the fungal attack in each bottle and allowed to stand for 8 weeks (Figure 1). At the end of the exposure period the blocks were removed and the mycelium were brushed off. The specimens were then oven dried for 24 hours and re-weighed $\left(\mathrm{W}_{2}\right)$ for the calculation of weight loss.

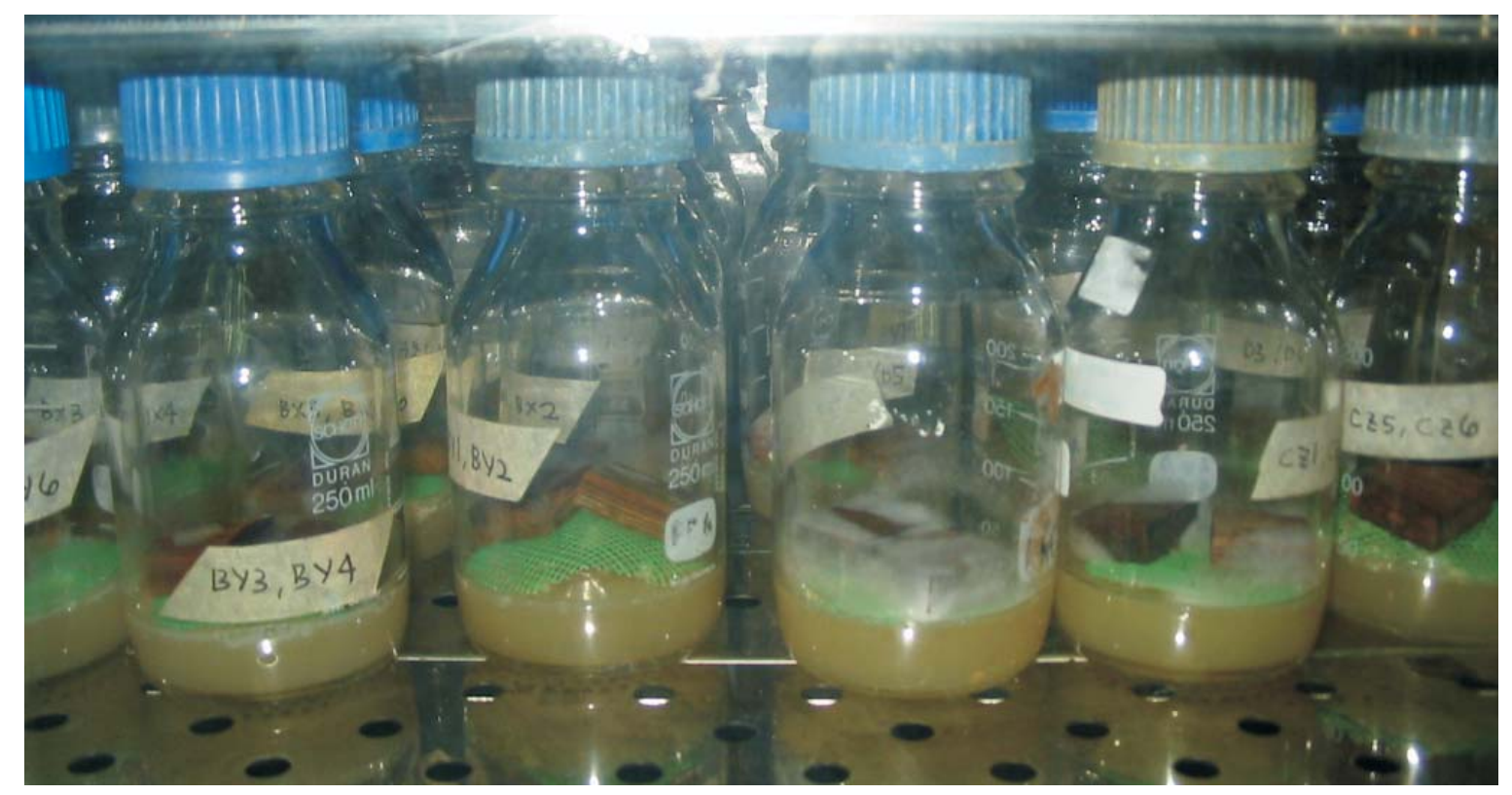

Figure 1. Assemblies of biological test 


\section{Calculation}

The weight loss of the specimens were calculated as follows:

weight loss $(\%)=\frac{\mathrm{w} 1-\mathrm{w} 2}{w 1} \times 100 \%$

Where:

$\mathrm{W}_{1}=$ Oven dried weight of bamboo after heating in palm oil $(\mathrm{g})$

$\mathrm{W}_{2}=$ Oven dried weight of bamboo after fungi exposure $(g)$

\section{RESULTS AND DISCUSSION}

Generally, palm oil soaked bamboo blocks were successfully protected against fungal attack. Figure 2 shows the weight loss percentage of heat treated samples after the fungal test. The average weight loss of untreated bamboo is $12.8 \%$, which were higher than the loss of heat treated bamboo
$(8.87 \%)$. It indicates that heating bamboo blocks in hot palm oil was effectively protecting bamboo blocks from fungal attack. This result is similar to those mentioned by Leithoff and Peek (2001) that heat treatment of bamboo in oil bath can improve its natural durability against fungi.

The mass loss during heat treatment presumably derived from degradation of water soluble extractives such as starch in bamboo. Naturally high content of starch in bamboo has been reported by Liese (1998). High starch content causes bamboo susceptible to fungal attack. In this condition, the starch was presumably decreasing due to the treatment. However, the loss of starch content is not studied in this experiment. Does starch dilute in hot oil palm.

Based on the heat treatment duration, it can be seen from Figure 3, that the longer the treatment is the less of samples weight loss during biological test. In heating of $100^{\circ} \mathrm{C}$ for example, the average weight loss of 20,40 and 60 minutes heating is

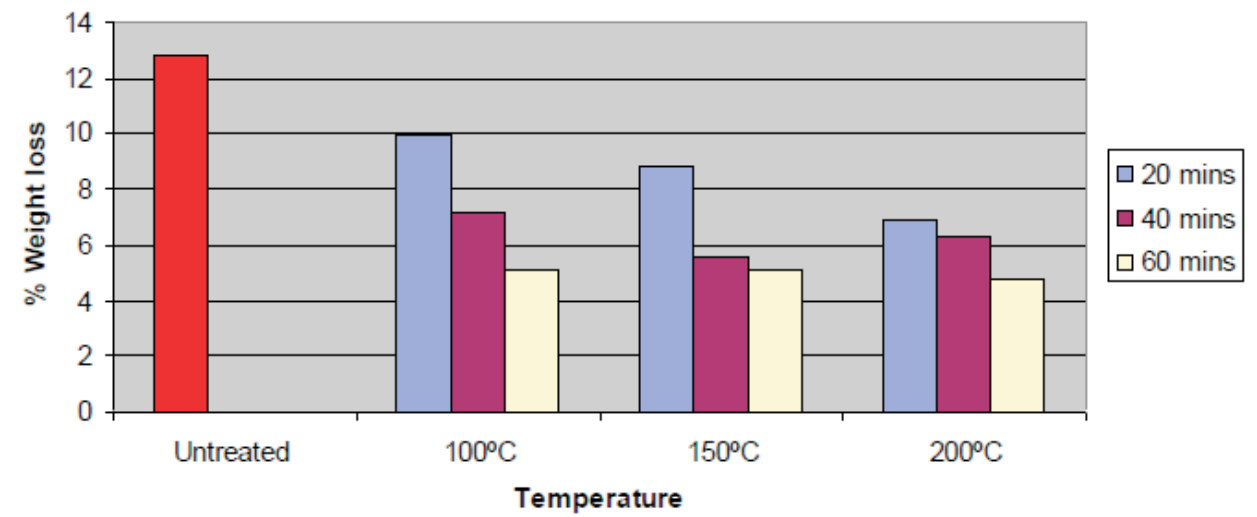

Figure 2. Comparison of weight loss in exposed bamboo blocks at various heating treatment temperatures in palm oil

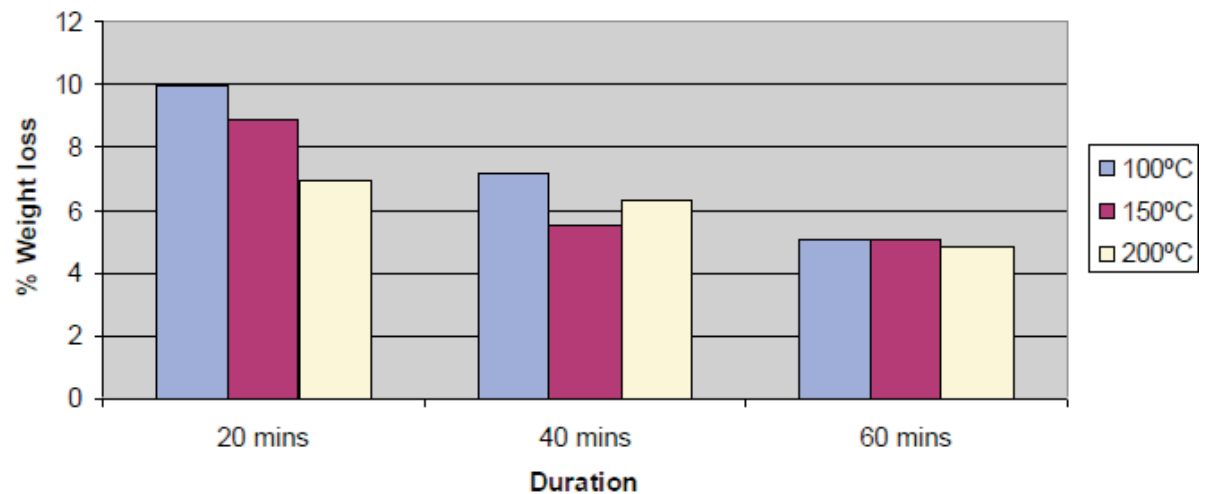

Figure 3. Comparison of weight loss in exposed bamboo blocks at various heating treatment duration in palm oil. 
$9.9 \%, 8.9 \%$ and $6.9 \%$, which mean heating bamboo at $100^{\circ} \mathrm{C}$ for 60 minutes can improve its durability. Similar pattern is also shown in heating bamboo at $150^{\circ} \mathrm{C}$ and $200^{\circ} \mathrm{C}$. Analysis of variance also shown that the F-test of temperature and duration differences acquire F-value of 532.16 and 290.199 for temperature and duration differences respectively. P-value of both factors are less than 0.001 (P-value $<0.001$ ) suggesting that data are not consistent with null hypothesis. In other word, three different heating times and three different temperatures are significantly different. The longer heating treatment allowed more palm oil to be taken up by the bamboo blocks in comparison to the shorter ones.

Different heating temperatures resulted in different weight loss, during biological test. The higher the temperature is the lower the weight loss during test. It indicates that more starch content was reduced after heating treatment which phenomena the strach was reduced by hot oil palm. The averages of sample weight loss are $9.9 \%, 7.2 \%$ and $5.1 \%$ in the heating temperature of $100^{\circ} \mathrm{C}, 150^{\circ} \mathrm{C}$ and $200^{\circ} \mathrm{C}$. It is postulated that with increasing temperature the bamboo substrates vulnerable to fungal attack have been rendered inert or unrecognizable as a food source. The higher temperature of treatment the more starch content in bamboo samples will presumably reduces.

\section{CONCLUSION}

From the study, it was found that:

1. Generally, bamboo blocks that soaked in hot palm oil were effectively enhanced its durability against fungal attack. It will be better: before state the results please indictes what the meaning of heat treatment.

2. The weight losses of bamboo samples were decreased with the increase of heating time. This indicates that the longer the heating treatment, the more durable of bamboo against the fungi.

3. The weight losses of bamboo samples were decreased with the increase of temperature of the treatment. This indicates that the higher temperature, the more durable of bamboo against fungi.
4. Based on the above findings it can be concluded that hot palm oil treatment has a potential to prolong the bamboo's service life, and therefore these encouraging research results deserve further development towards large-scale application.

\section{REFERENCES}

Beeson, C.F.C. 1941. Ecology and control of forest insects of India and neighbouring countries. Vasant Press, Dehra Dun India.

Chen, Y., Quin , W., Li, X., Gong, J. and Ni, M. 1985. Study on chemical composition ten species of bamboo. Chem. Ind. Ford. 5: 39-46.

Gardener, J.C.M. 1945. A note of the insect borers of bamboo and their control. Ind. For. Bull. Ent. (NS) Ent 125, Ghavami, K. and Moreira, L.E. 1992. Bamboo space structures. International symposium on industrial use of bamboo, Beijing, International Tropical Timber Organisation, Chinese Academy of Forestry, Beijing China.

Gnanaharan, R., Mohanan, C. and Chand Basha, S. 1993. Post-harvest technology of reed bamboo. BIC India Bull. 3(1): 1-6. 5

Leithoff, H. and Peek, R.D. 2001. Heat treatment of bamboo. IRG/WP 01-40216. The 32rd IRG-WP Annual Meeting Nara, Japan.

Liese, W. 1980. Preservation of bamboos. In "Bamboo Research in Asia" G. Lessard and A. Chouinard (Eds), IRDC, pp 165-172.

Liese, W. 1985. Bamboos biology silvics, properties, utilisation. GTZ, Eschborn, Germany, pp 132.

Liese, W. 1998. The anatomy of bamboo culms. Report No.18. International Network for Bamboo and Rattan, Beijing, China, p.204.

Mathew, G. and Nair, K.S.S. 1990. Storage pests of bamboos in Kerala. In "Bamboos: Current Research".I.V.R. Rao. R. Gnanaharan, and C.B. Sastry (Eds) Proc. International Bamboo Workshop, KFRI/IDRC, pp 212214.

Rehman, M.A. and Ishaq, SM. 1947. Seasoning and shrinkage of bamboo. Ind. For. Rec. (New Series) Utilisation 4(2): 1-22. 
Tamolang, F.N., Lopez, F.R., Semana, J.A., Casin, R.F. and Espiloy, Z.B. 1980. Properties and utilisation of Philipine bamboos. In "Bamboo Research in Asia" G. Lessard and A. Chouinard (Eds), IDRC, pp 189-200.
Tewari, D.N. 1993. A monograph on bamboo. International Book Distributers, Dehra Dun. India, pp 98. 